\title{
HOW DOES THE PRESENCE OF ENDOSPERM AFFECT SEED SIZE AND GERMINATION?
}

\author{
Susana Valencia-Díaz ${ }^{1}{ }^{4}$, Alejandro Flores-Morales ${ }^{2}$, Alejandro Flores-Palacios ${ }^{3}$ \\ and Irene Perea-Arango ${ }^{1}$ \\ 'Centro de Investigación en Biotecnología. Universidad Autónoma del Estado de Morelos, \\ Cuernavaca Morelos, México. \\ ${ }^{2}$ Facultad de Ciencias Biológicas. Universidad Autónoma del Estado de Morelos, Cuernavaca, Morelos, México. \\ ${ }^{3}$ Centro de Investigación en Biodiversidad y Conservación. Universidad Autónoma del Estado de Morelos, \\ Cuernavaca Morelos, México. \\ ${ }^{4}$ Author for correspondence: susana.valencia@uaem.mx
}

\begin{abstract}
Endospermic seeds may germinate more successfully than non-endospermic seeds. The quantity of reserves of endosperm is directly related to seed size; large seeds may present faster and higher percentages of germination than small seeds. We investigate whether capacity and time of germination differ between seeds with and without endosperm in two species of Brassicaceae (Lepidium virginicum and Brassica rapa) and two species of Fabaceae (Crotalaria pumila and Medicago sativa). We also investigate whether seed size within each seed type influences the percentage and time of germination. Seeds were collected from populations of these species, weighed and classified as large or small. Large and small seeds of species of both families, with both endospermic and non-endospermic seeds, were germinated under controlled conditions. Endospermic Brassicaceae seeds presented a higher percentage of germination than the non-endospermic seeds; however germination times were similar between seed type and seed size. Non-endospermic seeds of Fabaceae germinated more than the endospermic seeds of the same family, non-endospermic seeds also germinate faster. Regardless of the presence of endosperm, large seeds presented a higher percentage of germination than small seeds. However, it is not possible to generalize that seeds with endosperm will be of greater size and thus present higher percentages of germination, since the species of Fabaceae do not fit this pattern. It is inferred that the endosperm acts as a storage tissue in Brassicaceae, while in Fabaceae it may function more as a protective barrier for the embryo, but confirmation of this would require further research.
\end{abstract}

Key words: Brassicaceae, cotyledons, dicotyledons, embryo, Fabaceae.

Resumen: Semillas endospérmicas tendrían una germinación más exitosa que semillas no endospérmicas. La cantidad de reservas del endospermo guarda una relación directa con el tamaño de las semillas; semillas grandes tendrían mayor porcentaje y tasa de germinación que semillas pequeñas. Investigamos si el porcentaje y el tiempo de germinación difiere entre semillas con y sin endospermo en dos especies de Brassicaceae (Lepidium sativum y Brassica rapa) y dos especies de Fabaceae (Crotalaria pumila y Medicago sativa). Se investigó también si el tamaño de las semillas dentro de cada tipo de semilla influye en su porcentaje y tiempo de germinación. Se colectaron semillas de poblaciones de las especies mencionadas, se pesaron y se clasificaron en semillas chicas y grandes. Las semillas chicas y grandes de especies con semillas endospérmicas y no endospérmicas de ambas familias se germinaron en condiciones controladas. Las semillas endospérmicas de Brassicaceae tuvieron mayor porcentaje de germinación que las no endospérmicas, sin embargo el tiempo de germinación fue similar entre tipo y tamaños de semillas. Las semillas no endospérmicas de Fabaceae germinaron más y más rápido que las semillas endospérmicas de la misma familia. Independientemente de la presencia de endospermo, las semillas grandes tuvieron mayor porcentaje de germinación que las pequeñas. No se puede generalizar que semillas con endospermo tendrán mayor tamaño y mayor porcentaje de germinación, ya que las especies de Fabaceae no se ajustaron a esto. Se infiere que en Brassicaceae el endospermo actúa como tejido de almacenamiento mientras que en Fabaceae funcionaría más como barrera y protección al embrión, pero esto tiene que ser investigado.

Palabras clave: Brassicaceae, cotiledones, dicotiledóneas, embrión, Fabaceae.

$\mathbf{S}^{\mathrm{cos}}$ eed size has a direct relationship with resource availability (Lloret et al., 1999; Leishman et al., 2000; Moles and Westoby, 2004), prevailing environmental conditions during their development (Hodgson and Mackey, 1986; Valencia-Díaz and Montaña, 2005), dispersion syndrome and the size and lifecycle of the plant (Moles et al., 2005). Varia- 
tion in seed size is common among and even within individual plants (Leishman et al., 2000) and a trade-off exists between producing small seeds with a higher probability of spatial and temporal escape (Leishman et al., 2000; Moles et al., 2005) and large vigorous seeds with higher success in germination, in terms of a higher percentage and/or speed of germination (Marshall, 1986; Triphati and Khan, 1990; Vera, 1997; Tremayne and Richards, 2000; Moles et al., 2000; Moles and Westoby, 2004), emergence and/or seedling growth (Leishman and Westoby, 1994; Osunkoya et al., 1994; Seiwa, 2000; Moles and Westoby, 2004).

Seed size also varies among taxa; families such as Arecaceae produce large seeds (Moles et al., 2005) that can weigh up to $10^{4} \mathrm{~g}$ (Leishman et al., 2000), while the seeds of families such as Orchidaceae (Arditti et al., 2000) can weigh $10^{-06} \mathrm{~g}$ (Leishman et al. 2000). Seed size is related to the presence of storage tissue (Hodgson and Mackey, 1986; Rask et al., 2000; Moles et al. 2005) such as cotyledons and endosperm (Bewley and Black, 1985). Endosperm is an extra embryonic storage tissue, with high cellular metabolic activity, that surrounds and protects the embryo (IglesiasFernández et al., 2007). Once the seed has imbibed moisture, enzymes are released that mobilize the endosperm reserves towards the embryo, providing it with energy in order for germination to take place (Pritchard et al., 2002; Kucera et al., 2005).

The presence of endosperm is not a constant characteristic of dicotyledons (Rask et al., 2000), since the embryos of some dicotyledonous plants reabsorb this tissue and the reserves contained in the cotyledons; however, the persistence of endosperm as a storage tissue may indicate a relationship with germination characteristics (Costa et al., 2004). There are families, such as Brassicaceae and Fabaceae, with species that produce seeds with endosperm and other species with seeds in which this tissue is absent (Ledingham, 1949; Corby et al., 2011; Lee et al., 2012). Specifically, in certain species of Fabaceae, there is a positive relationship between the presence of nitrogen-fixing nodules and the size of the endosperm, since these nodules increase the nitrogen content of the endospermic tissue (Corby et al., 2011). For this reason, if seed size is related to the size of storage organs and thus to the quantity of reserves, large seeds and those with endosperm would present a faster or higher percentage of germination under optimum conditions than small seeds and those with no endosperm. The objectives of this study were therefore to determine whether the percentage of germination and mean germination time of seeds differs between endospermic and non-endospermic seeds in two species of Brassicaceae (Lepidium virginicum L. and Brassica rapa L.) and two species of Fabaceae (Crotalaria pumila Ortega and Medicago sativa L.) and whether seed size within each seed type (endospermic and non-endospermic) influences both the percentage of germination and mean germination time. It is hypothesized that seeds with endosperm will present faster and higher percentages of germination than those without, and that large seeds will have faster and higher germination than small seeds, regardless of the presence or absence of endosperm. The families Brassicaceae and Fabaceae were chosen for study because they include species with both seed types, thus reducing error as a result of phylogenetic confusion.

\section{Materials and Methods}

Species and collection site. Seeds of all the study species, apart from Medicago sativa, were collected in the surroundings of the urban zone of Cuernavaca, Morelos state, Mexico (18 $55^{\prime} 07^{\prime \prime} \mathrm{N}, 9^{\circ} 14^{\prime} 03^{\prime \prime} \mathrm{W}$; average elevation of 1,500 $\mathrm{m}$ a.s.1.). Seeds of $M$. sativa were collected in Techaluta, Jalisco state, Mexico $\left(20^{\circ} 04^{\prime} 27^{\prime \prime} \mathrm{N}, 103^{\circ} 33^{\prime} 10^{\prime \prime} \mathrm{W}\right.$, $1400 \mathrm{~m}$ a.s.l.). Mean summer temperature (years 1902 to 2011) in the urban zone of Cuernavaca (Huitzilac, Xochitepec, Cuernavaca, Jiutepec and Emiliano Zapata) is $21^{\circ} \mathrm{C}$, while average summer precipitation is $221.2 \mathrm{~mm}$ (Atlas Climático Digital de México, 2013). In Techaluta, the average summer temperature is $22^{\circ} \mathrm{C}$ and average summer precipitation is $162.2 \mathrm{~mm}$ (Atlas Climático Digital de México, 2013). Following their fruiting pattern, mature fruits were collected from 20 plants each of Brassica rapa (Brassicaceae) and Lepidium virginicum (Brassicaceae) in December of 2012. In April-Mayo f 2013, mature fruits were collected from 34 plants of Crotalaria pumila (Fabaceae) and from 50 plants of $M$. sativa (Fabaceae). The fruits were stored in paper bags and transported to the Ecology Laboratory of CIByC-UAEM, where they were stored at ambient temperature. Since fruits of the different species were collected at different times of the year, the mean storage temperature was $22^{\circ} \mathrm{C}$ for fruits of $B$. rapa and L. virginicum, and $25^{\circ} \mathrm{C}$ for fruits of C. pumila and M. sativa. Fruits were stored for approximately one month prior to initiation of the experiments.

In general, the family Brassicaceae includes annual herbaceous and subshrub species (Bustamante and Fonseca, 2009). It contains 338 genera and 3,709 species (Al-Shehbaz et al., 2006) and includes species with endospermic seeds and species with non-endospermic seeds; for example, Lepidium is a genus in which the seeds have a thin layer of endosperm, while mature seeds of the species of Brassica have no endosperm (Håkansson, 1956; Müller et al., 2006).

The family Fabaceae includes trees, shrubs, vines, lianas and herbaceous plants, containing 550 genera and 12,00017,000 generally cosmopolitan species (Andrade et al., 2007). This family also has species with seeds that have endosperm that functions as storage tissue and species with cotyledons that fulfill this role (Corby et al., 2011). Crotalaria pumila is a species with endospermic seeds (Miller, 1967), while the mature seeds of domesticated Medicago sativa do not present endosperm (Ledingham, 1940). 
Seed size. Seeds were extracted from the collected fruits of the four species described previously and seeds were sampled according to species with (Crotalaria pumila and Lepidium virginicum) and without (Medicago sativa and Brassica rapa) endosperm. From each set of sampled seeds, 200 seeds were chosen at random from each of the following species: M. sativa, B. rapa, and C. pumila. Each seed from these samples was weighed on a digital balance accurate to $0.001 \mathrm{~g}$ (Sartorius CP1245). Taking as a reference the data obtained from each sample of seeds of $C$. pumila, M. sativa, and $B$. rapa, a frequency histogram that comprised seven size class intervals was produced. Small seeds were considered those that occupied the first three size class intervals and large seeds those that were in the last three intervals. Intermediate seeds were not considered because their lower limit approached the upper limit of the third interval of the small seeds and their upper limit approached the lower limit of the first interval of the large seeds. Thus, two distinct seed sizes were considered: large and small.

Since the individual weight of the Lepidium virginicum seeds was undetected by the balance, we did not produce a frequency histogram. Instead, the seeds were separated visually into ten groups of large and ten groups of small seeds. Each group was of ten seeds, and therefore the samples of each size category comprised a total of 100 seeds. Each group of ten seeds was weighed on a digital balance (Sartorius $\mathrm{CP} 1245$, accuracy of $0.001 \mathrm{~g}$ ) and differences between small and large seeds of $L$. virginicum were detected using a $t$ student test (Zar, 2010).

Germination experiments. Prior to seed germination experiments, seeds of the four species were weighed and classified into small or large seeds, according to weight. To prove the hypothesis that large seeds and those with endosperm would present a higher percentage of germination than small and non-endospermic seeds, 20 seeds were sown in a Petri dish using filter paper moistened with $4 \mathrm{ml}$ of distilled water as a substrate. In total, ten experimental units or Petri dishes were used per treatment (species/seed size; $\mathrm{n}=200$ seeds). Due to the fact that the seeds of Crotalaria pumila did not germinate in preliminary experiments, these were scarified with fine grade sandpaper (FandeliA99 280), following studies where seeds of this family are mechanically scarified prior to germination (Probert et al., 2009). The scarified seeds were thoroughly rinsed with distilled water prior to sowing in order to remove any impurity or external agent that could contaminate the experiment. Once the seeds of all the species were sown, the Petri dishes were sealed with parafilm (Pechiney-Plastic Packaging, model PM-996, USA) and clingfilm (Kirkland Signature, model 26761, USA) to avoid moisture loss. The Petri dishes with the seeds were placed in a bioclimatic chamber (Scorpion Scientific A 50624, Mexico) under a photoperiod of $12 \mathrm{~h}$ light/12 h darkness at a constant tem- perature of $22{ }^{\circ} \mathrm{C}$. Germination was recorded daily for ten days. Seeds were considered to have germinated on emergence of the radicle.

Mean germination time. To determine whether seed germination time is affected by seed size and the presence or absence of endosperm, mean germination time was calculated with the following formula (Ranal and García de Santana 2006):

$$
\bar{t}=\sum_{\mathrm{i}=1}^{k} n_{\mathrm{i}} t_{\mathrm{i}} / \sum_{\mathrm{i}=1}^{k} n_{\mathrm{i}}
$$

Where $\bar{t}$ represents the time (in days) of the experiment, $n$ indicates the number of germinated seeds in day $i, i=$ day 1 , day 2 , day $3 \ldots$ day 10 and $k$ is the total duration of the experiment in days.

Statistical analysis. Differences between the weight of the endospermic and non-endospermic seeds of the two different families were determined using a $t$-student test (Zar, 2010). In order to determine whether the dependent variables percentage of germination and mean germination time $(\bar{t})$ varied between endospermic and non-endospermic seeds and between sizes within each seed type, a hierarchical analysis of variance was performed per taxonomic family (Zar, 2010), where the first level was seed type (endospermic vs. non-endospermic) and the second level was seed size (small vs. large). In the case of differences within each level, a Tukey multiple comparisons test was used. In order to achieve normality of data, the variable percentage of germination of the seeds was arcsine transformed and the variable mean germination time was standardized to $z$ values (Zar, 2010). All analysis was conducted using the statistical package Stata 13 (StataCorp, 2013).

\section{Results}

Seed size. In the Brassicaceae, the weight of Brassica rapa seeds was $(\bar{x} \pm \mathrm{SE}) 0.0021 \pm 0.0004 \mathrm{~g}$. This was lower $(t=-26.95, P<0.001)$ than the weight of the endospermic seeds of Lepidium virginicum $(0.0042 \pm 0.0004 \mathrm{~g})$. Based on the weight class categories of the seeds of B. rapa, small seeds were considered to be those of between 0.0008 and $0.0018 \mathrm{~g}$ ( $39 \%$ of the total number of seeds) and large seeds between 0.0023 and $0.0034 \mathrm{~g}$ ( $42 \%$ of the total number of seeds; Figure 1A). There were statistically significant differences $(t=21.39, P<0.05)$ between small $(0.0039 \pm 0.0001 \mathrm{~g})$ and large seeds $(0.0046 \pm 0.0002 \mathrm{~g})$ of the non-endospermic species L. virginicum.

Within the family Fabaceae, the endospermic seeds of Crotalaria pumila weighed more $(t=4.76, P<0.001$; $0.0028 \pm 0.0005 \mathrm{~g}$ ) than the non-endospermic seeds of Medicago sativa $(0.0023 \pm 0.0004 \mathrm{~g})$. Small seeds of $C$. pumila weighed between 0.0015 and $0.0027 \mathrm{~g}$ (38\% of the total number of seeds) while large seeds of this species weighed 

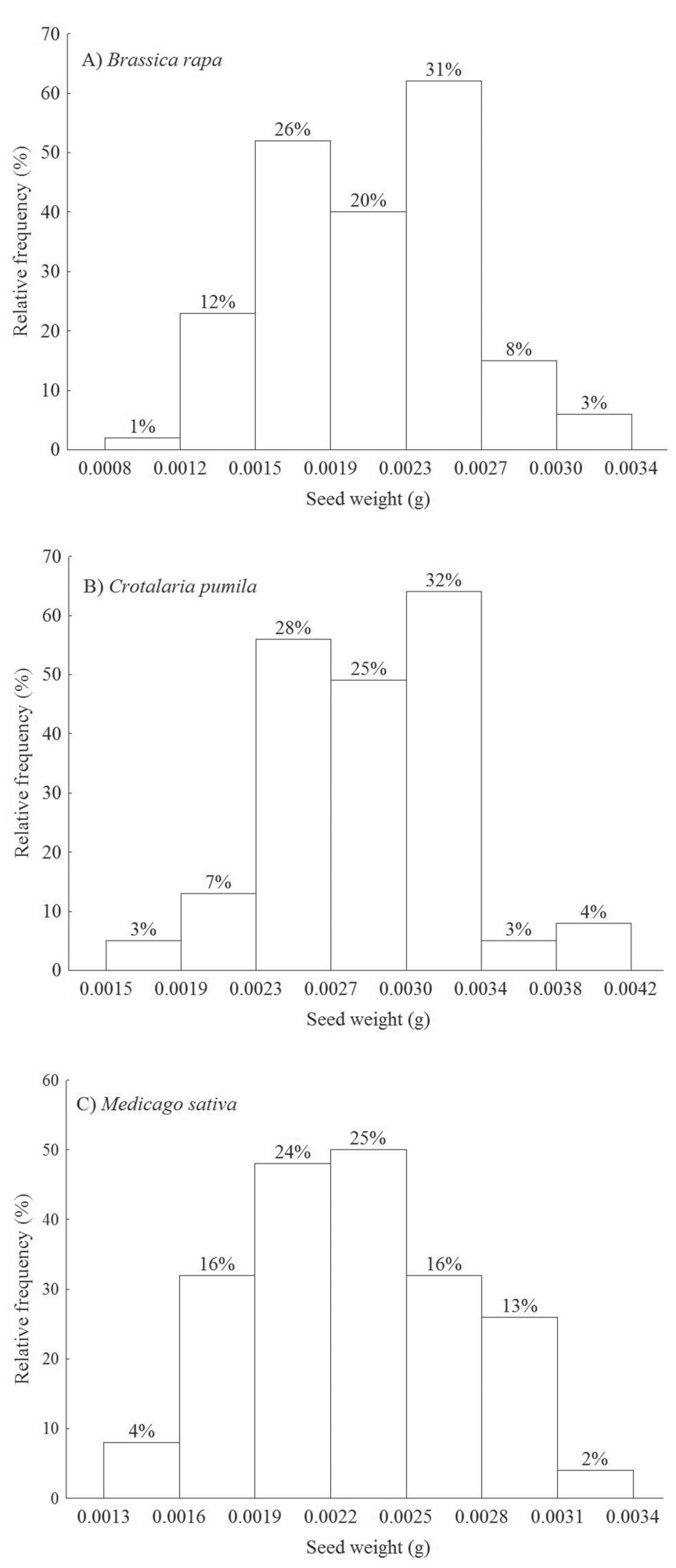

Figure 1. Histogram of frequencies of seed weights of a non-endospermic species of Brassicaceae (Brassica rapa) and of two species of Fabaceae (Crotalaria pumila, endospermic species and the non-endospermic Medicago sativa). The small seeds are those of the first three size classes, while the final three size classes comprise the large seeds.

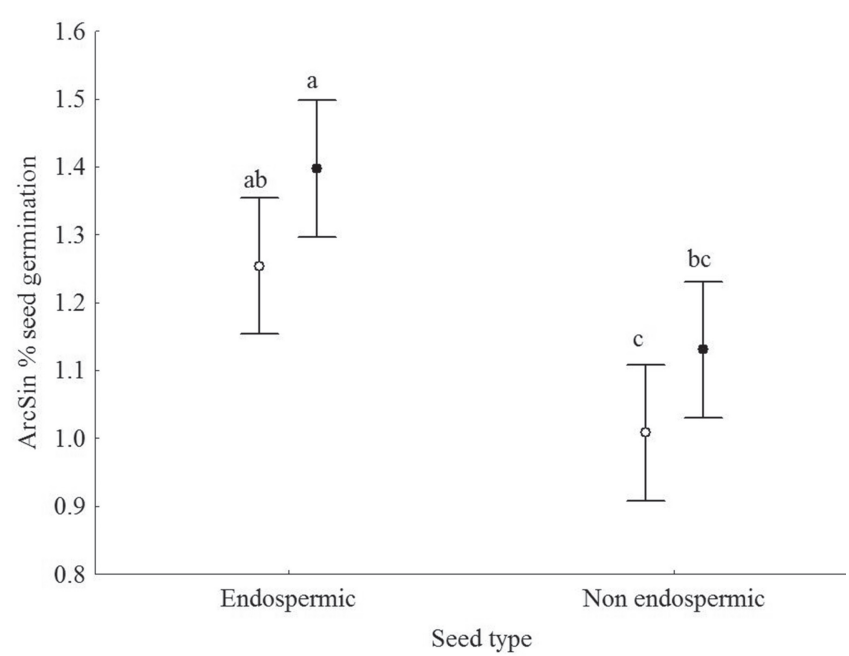

Figure 2. Percentage of seed germination of Lepidium virginicum (endospermic seeds) and Brassica rapa (non-endospermic seeds). Data were arcsine transformed. Circles denote the mean and lines represent the $95 \%$ confidence intervals. Open circles are small seeds and black circles are large seeds. Different letters indicate statistically significant differences $(P<0.05)$.

0.0030 to $0.0042 \mathrm{~g}$ (39\% of the total number of seeds; Figure 1B). Small seeds of $M$. sativa weighed between 0.0013 and $0.0022 \mathrm{~g} \mathrm{(44 \%} \mathrm{of} \mathrm{the} \mathrm{total} \mathrm{number} \mathrm{of} \mathrm{seeds)} \mathrm{and} \mathrm{large}$

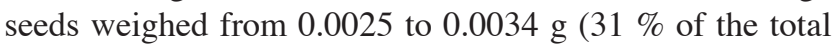
number of seeds; Figure 1C).

Seed germination. There were statistically significant differences $\left(F_{1,36}=26.72, P<0.001\right)$ between the percentage of germination of endospermic $(91.75 \pm 7.30 \%)$ and nonendospermic $(75.50 \pm 13.65 \%)$ seeds. In other words Lepidium virginicum have higher percentage of seed germination than Brassica rapa. Within seed type, there were statistically significant differences among the germination (\%) of seeds of different sizes $\left(F_{2,36}=3.60, P=0.03\right)$, with the following order of percentages of seed germination observed: large endospermic $(95 \pm 4.71 \%)$, small endospermic (88.5 $95 \pm 8.18 \%)$, large non-endospermic $(81 \pm 8.75 \%)$, small non-endospermic $(70 \pm 15.81 \%$, Figure 2$)$. Significant differences occur in the extremes of this gradient.

Regarding the family Fabaceae, there were differences $\left(F_{1,36}=38.42, P<0.001\right)$ between the percentages of germination of the endospermic $(79.25 \pm 6.34 \%)$ and nonendospermic $(92.25 \pm 8.50 \%)$ seeds. Seeds of $M$. sativa presented higher percentages of germination than those of $C$. pumila. Seed germination was different between sizes within the endospermic and non-endospermic seeds $\left(F_{1,36}=6.60, P<0.005\right)$. Percentages of seed germination followed a gradient from large non-endospermic $(96.50 \pm$ $3.37 \%)$, small non-endospermic $(88.00 \pm 10.05 \%)$, large endospermic $(85.50 \pm 0.00 \%)$ and small endospermic $(79.25 \pm 6.34 \%$, Figure 3$)$. Significant differences occur in the extremes of this gradient. 


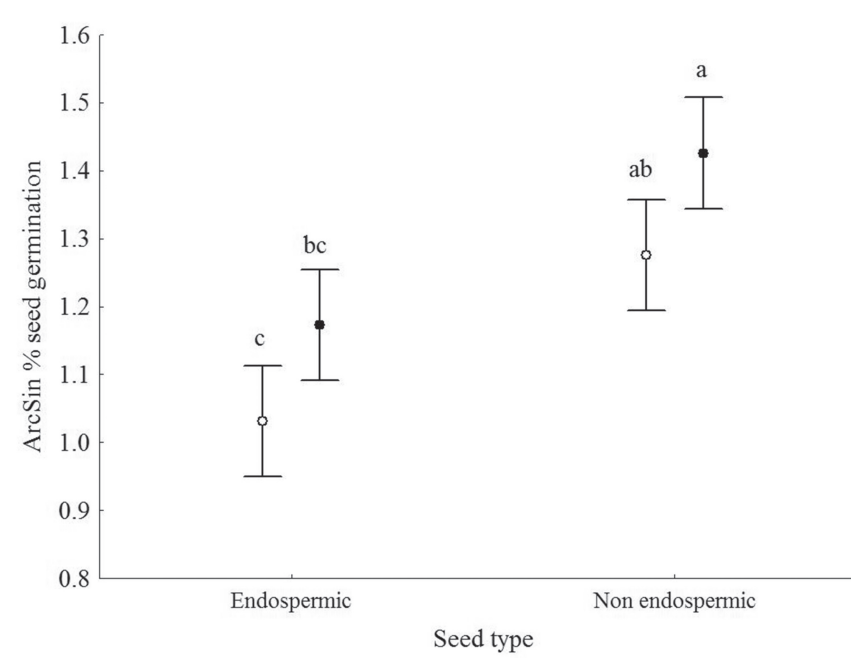

Figure 3. Percentage of seed germination of Crotalaria pumila (endospermic seeds) and Medicago sativa (non-endospermic seeds). Data were arcsine transformed. Circles denote the mean and lines represent the $95 \%$ confidence intervals. Open circles are small seeds and black circles are large seeds. Different letters indicate statistically significant differences $(P<0.05)$.

Mean germination time. For Brassicaceae species, there were no statistically significant differences $\left(F_{1,36}=1.64, P=0.21\right)$ between the mean germination time of endospermic $(2.51 \pm$ 0.13 days) and non-endospermic (2.58 \pm 0.21 days) seeds. Within seed type, there were significant statistical differences between large and small seeds $\left(F_{1,36}=3.30, P<0.05\right)$. Mean germination time of large endospermic seeds was $2.46 \pm$ 0.120 days, followed by the large non-endospermic $(2.50 \pm$ 0.204 days $)$, small endospermic $(2.57 \pm 0.13$ days $)$ and small non-endospermic (2.60 \pm 0.20 days) seeds. Significant differences occur in the extremes of this gradient.

Regarding the family Fabaceae, there were statistically significant differences $\left(F_{1,36}=316.27, P<0.001\right)$ between the mean germination time of endospermic $(3.90 \pm 0.36$ days) and non-endospermic (2.31 \pm 0.36 days $)$ seeds. On the other hand, mean germination time between seed sizes within seed type was similar $\left(F_{1,36}=0.57, P=0.57\right)$. Large endospermic seeds have a mean germination time of $3.95 \pm$ 0.36 days, followed by the small endospermic $(3.85 \pm 0.38$ days), large endospermic $(2.30 \pm 0.09)$ and small non-endospermic $(2.27 \pm 0.17)$ seeds.

\section{Discussion}

Variation in the size of the endosperm is related to the reserves contained within the tissue (Corby et al., 2011) and this in turn influences seed size (Leishman et al., 2000). In the species of Brassicaceae, we found that the seeds of Lepidium virginicum are larger than those of Brassica rapa, which corresponds to the presence of endosperm. It should be noted that both species of Brassicaceae are herbaceous annuals and were collected the same study area in the same year. For this reason, the environmental conditions in which these seeds developed and the characteristics of their life histories are similar. Under this assumption, it is the reserves of the endosperm that would have direct repercussions on the seed size of L. virginicum.

Variation in seed size depends not only on ecological factors but also on the phylogeny because of the probability that traits that were successful for a predecessor (i.e. seed size) pass on to the descendants and are thus maintained through natural selection (Leishman et al., 2000). Despite the fact that the two species of Fabaceae belong to the same subfamily Papilionidae (Corby et al., 2011) and that both species come from the herbaceous stratum; the endospermic (Crotalaria pumila) seeds were smaller than the non-endospermic (Medicago sativa) seeds. This size difference may be due to the fact that the seeds of $M$. sativa come from a plantation where artificial selection over time may have favored large seeds. Furthermore, the seeds of $M$. sativa were collected in Techaluta, Jalisco, where the environmental conditions differ from those of the center of Morelos and the origin of these seeds in plantations implies that they will have had a constant supply of moisture during their formation.

When a plant assigns resources to its progeny, it faces a trade-off between the number and size of the seeds it produces. Producing many seeds increases the progeny in new sites but large seed size increases the probability that the seeds germinate early (Moles et al., 2000) and seedlings survive. There is evidence that plants preferentially tend to maximize seed size rather than increasing their number (Venable, 1992). While this study did not quantify the number of seeds of the study species, it was possible to observe that the percentages of small and large seeds were always greater than $30 \%$, suggesting that the plants of the study species produced seeds of variable size, possibly as a strategy to cope with variability in environmental conditions.

Unlike the monocotyledons, the endosperm is a storage tissue that is not found in all of the dicotyledonous species and its presence may vary depending on the developmental stage of the seed (Baroux et al., 2002). It is common for the endosperm to be absorbed by the embryo and for the cotyledons to function as storage tissues (Lopes and Larkins, 1993). Nevertheless, from an evolutionary perspective, the presence of specialized tissue confers advantages for the seed in terms of germination characteristics (i.e. percentage and germination time). The size of the endosperm also affects seed size and thus germination; large seeds have a higher probability of successful germination increasing the percentage and, in annuals, the incidence of early germination (Marshall, 1986; Triphati and Khan, 1990;Vera, 1997; Tremayne and Richards, 2000; Moles and Westoby, 2004). In this study, however, we did not find a consistent pattern that would indicate that the presence of endosperm always translates into a higher percentage of germination or faster germination. Higher percentage of germination was 
found only in endospermic seeds (Lepidium virginicum) of Brassicaceae, while faster germination was presented by the non-endospermic seeds (Medicago sativa) of Fabaceae.

The germination behavior of seeds in Brassicaceae did fit the proposed hypothesis, where the endospermic seeds presented higher percentages of germination than the nonendospermic seeds, i.e., the endosperm reserves affected the percentage of germination (Leishman et al., 2000). Moreover, the large seeds within each seed type geminated more than the small seeds. For this reason, we can corroborate that seed size is a life history characteristic upon which sensitive stages, such as germination, are dependent (Harper et al., 1970; Moles et al., 2005). However, mean germination time in Brassicaceae did not differ among types and sizes of seeds; this is similar to the results found by Eriksson (1999), who found no effect of seed size on germination time in Convallaria majalis.

The non-endospermic seeds of Fabaceae presented a higher percentage of germination; these seeds came from a crop of alfalfa (Medicago sativa), and thus there is a high probability that these had been selected in order to obtain close to $100 \%$ germination and that the presence of endosperm does not play a determining role. There is also evidence that, in certain species, the endosperm and testa of the seeds could act more as barriers that impede germination rather than storage organs; this is related to the physical dormancy of the seeds of certain species (Groot et al., 1988; Müller et al., 2006; Lee et al., 2012). Furthermore, the endosperm contains hormones (abscisic acid) that inhibit seed germination (Müller et al., 2006). Therefore, the lack of endosperm implies that the seeds of $M$. sativa do not have to break the walls of the endosperm that surrounds the embryo in order for protrusion of the radicle to occur, which may also result in faster germination. Indeed, the endospermic seeds of Crotalaria pumila had to be scarified in order to achieve successful germination.

Within each seed type of Fabaceae, seed size did influence the percentage of germination; the large seeds of the non-endospermic species had a greater percentage of germination than both small and large endospermic seeds (Crotalaria pumila). The differences are therefore gradual; analysis of these differences in the germination of large and small seeds of $C$. pumila revealed that there are no significant differences. This agrees with the findings of Miller (1967), who related the seed size of 400 species of Crotalaria with the quantity of endosperm present and found no relationship between these variables.

According to Costa and collaborators (2004), the functions of the endosperm are the translocation of food from the mother plant to the embryo, communication with the embryo, barrier formation and protection of the embryo as well as acting as a storage tissue. Based on the results of the study, we can infer that the seeds of Brassicaceae possess an endosperm that functions as a storage organ, as reflected in the size and percentage of germination obtained by the seeds of the two species studied here. Nevertheless, the Fabaceae seeds may have an endosperm that acts as a barrier or protection for the embryo, but this remains to be confirmed in a specific study. We conclude, however, that seed size is related to percentage of germination, i.e., large seeds present higher percentages of germination than small seeds. This is the first study to document the relationship between the presence of endosperm and the size and germination characteristics of phylogenetically related species.

\section{Acknowledgements}

We are grateful to T. Cruz-Fernández and O. Sotelo-Caro for their help in the field, to K. MacMillan for comments and English translation of the manuscript and to the ecology laboratory of $\mathrm{CIByC}$ for providing the facilities with which to conduct this research.

\section{Literature cited}

Al-Shehbaz I.A., Beilstein M.A. and Kellogg E.A. 2006. Systematics and phylogeny of the Brassicaceae (Cruciferae): an overview. Plant Systematics and Evolution 259:89-120.

Andrade M.G., Calderón de Rzedowski G., Camargo-Ricalde S.L., Grether R., Hernández H.M., Martínez-Bernal A., Rico L., Rzedowski J. and Sousa S.M. 2007. Familia Leguminosae, Subfamilia Mimosoideae. Flora del Bajío y de Regiones Adyacentes, Fascículo 150. Instituto de Ecología A.C., Patzcuaro.

Arditti J., Karim A. and Ghani A.K.A. 2000. Tansley Review No. 110. Numerical and physical properties of orchid seeds and their biological implications. New Phytologist 145:367-421.

Baroux C., Spillane C. and Grossniklaus U. 2002. Evolutionary origins of the endosperm in flowering plants. Genome Biology 3:reviews1026.1-reviews1206.5.

Bewley D.J. and Black M. 1985. Seeds: physiology of development and germination. Plenum Press, New York.

Bustamante R. and Fonseca R.M. 2009. Nueva especie de Romanschulzia (Brassicaceae) del estado de Guerrero, México. Acta Botanica Mexicana 87:23-29.

Atlas Climático Digital de México. 2013. Unidad de Informática para las Ciencias Ambientales (UNIATMOS), Centro de Ciencias de la Atmósfera, Universidad Nacional Autónoma de México. Disponible en: <http://atlasclimatico.unam.mx/atlas/ mor/mor.html > (Consultado en Junio 2014).

Corby D.L.H., Smith D.L. and Sprent J.I. 2011. Size, structure and nitrogen content of seeds of Fabaceae in relation to nodulation. Botanical Journal of the Linnean Society 167:251-280.

Costa L.M., Gutiérrez-Marcos J.F. and Dickinson H.G. 2004.More than a yolk: the short life and complex times of the plant endosperm. Trends in Plant Science 9:507-514.

Eriksson O. 1999. Seed size variation and its effect on germination and seedling performance in the clonal herb Convallaria majalis. Acta Oecologica 20:61-66.

Groot S.P.C., Kieliszewska-Rokicka B., Vermeer E. and Karssen C.M. 1988. Gibberellin-induced hydrolysis of endosperm cell walls in gibberellin-deficient tomato seeds prior to radicle protrusion. Planta 174:500-504. 
Håkansson A. 1956. Seed development of Brassica oleraceae and B. rapa after certain reciprocal pollinations. Hereditas 42:373396.

Harper J.L., Lovell P.H. and Moore K.G. 1970. The shapes and sizes of seeds. Annual Review of Ecology and Systematics 1:327-356.

Hodgson J.G. and Mackey J.M.L. 1986. The ecological specialization of dicotyledonous families within a local flora: some factors constraining optimization of seed size and their possible evolutionary significance. New Phytologyst 104:497-515.

Iglesias-Fernández R., Matilla A.J., Pulgar I. and de la Torre F. 2007. Ripe fruits of Sisymbrium officinale L. contain heterogeneous endospermic seeds with different germination rates. Seed Science and Biotechnology 1:18-24.

Kucera B., Cohn M.A. and Leubner-Metzger L. 2005. Plant hormone interactions during seed dormancy release and germination. Seed Science Research 15:281-307.

Ledingham G.F. 1940. Cytological and developmental studies of hybrids between Medicago sativa and a diploid form of M. falcate. Genetics 25:1-15.

Lee K.J.D., Dekkers J.W.B., Steinbrecher T., Walsh Ch.T., Bacic A., Bentsink L., Leubner-Metzger G. and Knox J.P. 2012. Distinct cell wall architectures in seed endosperms in representatives of the Brassicaceae and Solanaceae. Plant Physiology 160:1551-1566.

Leishman M.R. and Westoby M. 1994.The role of seed size in seedling establishment in dry soil conditions-experimental evidence from semi-arid species. Journal of Ecology 82:249-258.

Leishman M.R., Wright I.J., Moles A.T. and Westoby M. 2000. The evolutionary ecology of seed size. In: Fenner M. Ed. Seeds: The Ecology of Regeneration in Plant Communities, pp. 31-57, CABI Publishing, Wallingford.

Lloret F., Casanovas C. and Peñuelas J. 1999.Seedling survival of Mediterranean shrubland species in relation to root: shoot ration, seed size and water and nitrogen use. Functional Ecology 13:210-216.

Lopes M.A. and Larkins B.A. 1993. Endosperm origin, development, and function. The Plant Cell 5:1383-1399.

Marshall D.L. 1986. Effect of seed size on seedling success in three species of Sesbiana (Fabaceae). American Journal of Botany 73:457-464.

Miller R.H. 1967. Crotalaria seed morphology, anatomy, and identification. Technical Bulletin No. 1373.Agricultural Research Service, United States Department of Agriculture, Washington. D.C.

Moles A.T., Hodson D.W. and Webb C.J. 2000. Seed size and shape and persistence in the soil in the New Zealand flora. Oikos 89:541-545

Moles A.T. and Westoby M. 2004. Seedling survival and seed size: a synthesis of the literature. Journal of Ecology 92:372-383.

Moles A.T., Ackerly D.D., Webb C.O., Tweddle J.C., Dickie J.B. and Westoby M. 2005. A Brief history of seed size. Science 307:576-580.

Müller K., Tintelnot S. and Leubner-Metzger G. 2006. Endospermlimited Brassicaceae seed germination: Abscisic acid inhibits embryo-induced endosperm weakening of Lepidium sativum (cress) and endosperm rupture of cress and Arabidopsis thaliana. Plant Cell Physiology 47:864-877

Osunkoya O.O., Ash J.E., Hopkins M.S. and Graham A.W. 1994. Influence of seed size and seedling ecological attributes on shade-tolerance of rain-forest tree species in northern Queensland. Journal of Ecology 82:149-163.

Pritchard S.L., Charlton W.L., Baker A. and Graham I.A. 2002. Germination and storage reserve mobilization are regulated independently in Arabidopsis. The Plant Journal 31:639-647.

Probert R.J., Daws M.I. and Hay R.F. 2009. Ecological correlates of ex situ seed longevity: a comparative study on 195 species. Annals of Botany 104:57-69.

Ranal M.A. and Garcia de Santana D. 2006. How and why to measure the germination process? Revista Brasileira de Botanica 29:1-11.

Rask L., Andréasson E., Ekbom B., Eriksson S., Pontoppidan B. and Meijer J. 2000. Myrosinase: gene family evolution and herbivore defense in Brassicaceae. Plant Molecular Biology 42:93-113.

Seiwa K. 2000. Effects of seed size and emergence time on three seedling establishment importance of developmental constraints. Oecologia 123:208-215.

StataCorp. 2013.Stata Statistical Software: Release 13. StataCorp LP, College Station.

Tremayne M.A. and Richards A.J. 2000. Seed weight and seed number affect subsequent fitness in outcrossing and selfing Primula species. New Phytologist 148:127-142.

Tripathi R.S. and Khan M.L. 1990. Effects on seed weight and microsite characteristics on germination and seedling fitness in two species of Quercus in a subtropical wet hill forest. Oikos 57:289-296.

Vera M.L. 1997. Effects of altitude and seed size and seedling survival of heathland plants in north Spain. Plant Ecology 133:101-106.

Valencia-Díaz S. and Montaña C. 2005. Temporal variability in the maternal environment and its effect on seed size and seed quality in Flourensia cernua DC (Asteraceae). Journal of Arid Environments 63:686-695.

Venable D.L. 1992. Size-number trade-off and the variation of seed size with plant resource status. The American Naturalist 140:287-304.

Zar J.H. 2010. Biostatistical Analysis. Pearson, New Jersey.

Received: September 15, 2014

Accepted: November 25, 2014 